\title{
14
}

\section{Addressing Homelessness: Does Australia's Indirect Implementation of Human Rights Comply with its International Obligations?}

DIANNE OTTO

Successive Australian governments have chosen, in the main, not to directly incorporate Australia's international human rights obligations into domestic law. That is, with some important exceptions, they have not taken the path of adopting legislation, or promoting constitutional change, which would bring international human rights law directly into Australian law and make it amenable to judicial enforcement. ${ }^{1}$ Nor have Australian governments followed the lead of their Commonwealth compatriots by adopting some form of intermediate approach, which would empower courts to interpret legislation consistently with its international human rights obligations while retaining parliamentary supremacy, as in Canada, ${ }^{2}$ New Zealand, ${ }^{3}$ and the United Kingdom. ${ }^{4}$ While it is true that some human rights are directly protected by the Australian Constitution, ${ }^{5}$ by

1 The Australian government has the option of indirect implementation because treaties are generally non-self-executing in Australia, which means that constitutional amendment or legislation is necessary before treaty obligations are directly applicable in domestic law.

2 Canadian Charter of Rights and Freedoms 1982, s 33, empowers provincial and federal legislatures, by ordinary majority, to override Charter rights for a renewable period of five years ('notwithstanding' provision).

3 Bill of Rights Act 1990 (NZ), s6, requires that courts, wherever possible, prefer an interpretation of legislation that is consistent with the legislatively enacted Bill of Rights over any other interpretation, while $s 4$ provides that the Bill of Rights cannot invalidate inconsistent legislation.

4 The Human Rights Act 1998 (UK), s 3, requires that courts read and give effect to legislation in a way that is consistent with the European Convention for the Protection of Human Rights and Fundamental Freedoms 1950, while s 4 empowers the courts to declare legislation incompatible with the Convention, but only the Parliament is able to invalidate such legislation by amendment or repeal.

5 The express rights in the Commonwealth Constitution include the prohibition of laws limiting the free exercise of religion (s 116), a largely formal right to trial by jury for federal indictable offences (s 80), protection against discrimination on the basis of residence in one state rather than another (s 117), a guarantee that compulsory acquisition of property takes place on just terms (s 51 (xxxi)), and a guarantee that interstate trade, commerce, and intercourse be absolutely free (s 92 ). For a more expansive reading of express rights in the Australian Constitution, see P. Bailey, Human Rights: 
legislation, ${ }^{6}$ and by way of the common law, ${ }^{7}$ and that international human rights law can in certain circumstances influence statutory interpretation, the development of the common law, administrative decision-making, and constitutional interpretation, ${ }^{8}$ the coverage falls a very long way short of being either systematic or comprehensive when measured against Australia's international human rights obligations.

Instead, Australian governments have relied on the indirect effects of legislation and government policies and programmes to ensure the enjoyment of many human rights, including civil and political rights such as freedom of speech, the right to vote and the right to peaceful assembly, and most economic and social rights. As explained in its recent periodic report to the UN Committee on Economic, Social and Cultural Rights (CESCR), the Government believes that 'In many cases, rights are more readily promoted by less formal processes [than traditional legal sanctions], often associated with inquiry, conciliation and report.'9 This indirect approach is justified as being consistent with the institution of responsible government in a democracy, whereby human rights are best articulated and protected through democratic rather than judicial processes. ${ }^{10}$ Indeed, proponents of this argument urge that the right of everyone to be equally involved in decision-making about rights guarantees is itself a fundamental human right. ${ }^{11}$ Various other rationales for the Australian approach have included deference to federal constitutional arrangements, the fear of legalizing politics by attributing too much power to an unelected and

Australia in an International Context (Sydney: Butterworths, 1990), 84-6. The High Court of Australia has also recognized implied constitutional rights to freedom of political communication, movement, and association, and to procedural due process in the exercise of judicial power. For a comprehensive discussion of implied constitutional rights, see G. Williams, Human Rights Under the Australian Constitution (Melbourne: Oxford University Press, 1999).

6 The Racial Discrimination Act 1975 (Cth), Sex Discrimination Act 1984 (Cth), Human Rights and Equal Opportunity Commission Act 1986 (Cth), Disability Discrimination Act 1992 (Cth), and Crimes (Torture) Act 1998 (Cth) all directly implement, but in a more or less limited way, some of Australia's international human rights obligations. Further, the Human Rights (Sexual Conduct) Act 1994 (Cth) and the Privacy Act 1988 (Cth) partially implement the right to privacy, Art 17 of the International Covenant on Civil and Political Rights 1966. Many of these privacy, Art 17 of the be found in state and territory legislation. Some of Australia's international protections can also are also directly implemented through industrial relations legislation.

7 See Dietrich v The Queen (1992) 177 CLR 292, recognizing that the common law requirement of a fair trial requires, in most cases, that an indigent be provided with representation at public expense. But the human rights protecrions offered by the conmon law are limention at public relation to social and political equality and offed by the common law are limited, especially in wealth (1992) 174 CLR 455; and Kruger $v$ Commonwealth (1997) 146 ALR 126.

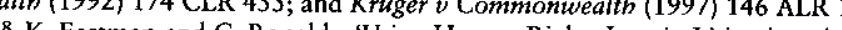

8 K. Eastman and C. Ronalds, 'Using Human Rights Law in Litigation: A Practitioner's Perspective', in D. Kinley (ed.), Human Rights in Australian Law (Sydney: Federation Press, 1998).

10 Third Periodic Report: Australia, 23/07/98, E/1994/104.Add/22, para 21.

10 Sir Robert Menzies, former Australian prime minister, gives a classic exposition of this view in Central Power in the Australian Commonwealth (Charlottesville: University Press of Virginia, 1967), 54. For a more sophisticated defence of democratic promotion and protection of human rights, see 1. Campbell, 'Democracy, Human Rights and Positive Law', (1994) 16 Sydney Law Review 195. 11 J. Waldron, 'A Right-Based Critique of Constitutional Rights', (1993) 13 Oxford Journal of Legal Studies 18. politicized judiciary, and an enduring commitment to utilitarianism. ${ }^{12}$ Even with respect to economic and social rights, the Australian argument has been more about the appropriate means of articulating and enforcing them than about their justiciability per se.

This chapter explores whether the Australian approach to implementing human rights, indirectly through democratic political processes rather than directly through judicial enforcement, fulfils Australia's obligations under international law to ensure that all Australians enjoy the human rights enumerated in the human rights treaties to which it is a party. Using the national Supported Accommodation Assistance Program (SAAP) ${ }^{13}$ as a case-study, I argue that the Australian system, in its present form, does not adequately implement Australia's international obligations because it does not, on its own terms, provide adequate non-judicial accountability mechanisms that would ensure 'effective remedies' for any violations. Ultimately, I am asking how Australians want to treat the most vulnerable and disadvantaged members of the community, and, in the expectation that the response will embrace the universal standards of human rights, I conclude that a revised mix of legal and political mechanisms that strengthens democratic debate and non-judicial enforcement, while also giving more power to courts than they currently enjoy yet maintaining parliamentary supremacy, will best achieve that humane, just, equitable, and democratic society.

\section{WHAT ARE AUSTRALIA'S INTERNATIONAL HUMAN RIGHTS} OBLIGATIONS?

My discussion will focus on the implementation of the International Covenant on Economic, Social and Cultural Rights 1966 (ICESCR), ${ }^{14}$ which is undoubtedly the most neglected human rights treaty in the Australian political and legal landscape. Until the end of the cold war this could be said to parallel a more general neglect of economic and social rights internationally, due partly to cold war ideological disputes about the proper limits of state power and partly to disputes within liberalism about the justiciability of economic and social 'rights'. ${ }^{15}$ The legacy of this era was a lack of normative development of many

$12 \mathrm{H}$. Charlesworth, 'The Australian Reluctance About Rights', in P. Alston (ed.), Towards an Australian Bill of Rights (Canberra: Centre for International and Public Law, 1994), 21, 22.

13 SAAP was the first nationally coordinated approach to addressing homelessness in Australia, commencing in 1985

14 International Covenant on Economic, Social and Cultural Rights 1966 (ICESCR), UN GA Res 2200A(XXI) (16 Dec. 1966).

15 See E. W. Vierdag, 'The Legal Nature of the Rights Granted by the International Covenant on Economic, Social and Cultural Rights', (1978) 9 Netherlands Yearbook of International Law 69 M. Cranston, What Are Human Rights? (New York: Taplinger, 1973), 65-71; contra G. J. H. van Hoof, 'The Legal Nature of Economic, Social and Cultural Rights: A Rebuttal of Some Traditiona Views', in P. Alston and K. Tomasevski (eds.), The Right to Food (The Hague: Martinus Nijhof 1984), 97, 98-102; K. D. Ewing, 'Social Rights and Constitutional Law', [1999] Public Law 104. 
of the rights enumerated in the ICESCR and a dearth of national institutions specifically committed to the promotion of economic and social rights. 16 The Australian Human Rights and Equal Opportunity Commission (HREOC), the most important of the Government's 'less formal' measures to promote human rights, is a prime example of the ambivalence towards economic and social rights at that time. The HREOC Act 1986 (Cth) failed to include the ICESCR in its scheduling of human rights instruments, which define 'human rights' for the purposes of the Act. ${ }^{17}$ This means that ICESCR rights are not even subject to the limited oversighting and conciliation functions of HREOC. While some of the rights enumerated in the ICESCR are nevertheless included by way of the other instruments listed in the Schedule, ${ }^{18}$ a large gap remains.

Since the end of the cold war, ambivalence about economic and social rights has altered significantly, with the inclusion of economic and social rights in many national constitutions, the adoption of a Collective Complaints Protocol to the European Social Charter 1961, and the tireless normative work of the CESCR, which was established in 1985 to monitor the implementation of the ICESCR. 19 At the centre of this changing landscape is a rejection of the earlier cartography that drew a distinction between rights according to whether they involved negative or positive implementation obligations. ${ }^{20}$ The misleading dualistic conceptualization has been superseded by a four-part typology of duties, which is applicable to all human rights. ${ }^{21}$ The typology layers state responsibility to fully realize every human right into four separate, yet interconnected, obligations

16 P. Alston, 'The Committee on Economic, Social and Cultural Rights', in P. Alston (ed.), The United Nations and Human Rights: A Critical Appraisal (New York: Oxford University Press, 1992),
473,474 . $473,474$.

17 The exclusion of the ICESCR was despite its entry into force for Australia, without reservation, on 10 Mar. 1976.

${ }^{18}$ All the scheduled instruments contain some economic and social rights: the International Covenant on Civil and Political Rights 1966 (ICCPR), UN GA Res 2200A(XXI) (16 Dec. 1966); the Convention Concerning Discrimination in Respect of Employment and Occupation 1958 (ILO) Convention no. 111); the Convention on the Rights of the Child 1989, UN GA Res 44/25 (20 Nov. 1989); the Declaration on the Rights of the Child 1959, UN GA Res 1386 (XVIV) (29 Nov. 1959), the Declaration on the Rights of Disabled Persons 1975, UN GA Res 3447 (XXX) (9 Dec. 1975); the Declaration on the Rights of Mentally Retarded Persons 1971, UN GA Res 2856 (XXVI) (20 Dec. 1971); and the Declaration on the Elimination of All Forms of Intolerance and of Discrimination Based on Religion or Belief 1981, UN GA Res 36/55 (25 Nov. 1981). 19 Unlike the other main human rights treaties, the ICESCR did not establish a treaty-monitoring
committee, but instead left this task to the Economic and Social Council (ECOSOC) ECOSOC established the CESCR as a subsidiary organ to fulfil this role in ECOSOC (ECOSOC). ECOSOC ESCOR Supp (no. 1) at 15, UN Doc E/1985/85 (1985). The CESCR consists 1985/17, 1985 UN serving in their personal capacity for four-year terms. They are elected by ECOSOC froteen experts nominated by states parties.

${ }^{20} \mathrm{H}$. Shue, Basic Rights: Subsistence, Affluence and US Foreign Policy (Princeton: Princeton University Press, 1980).

21 Building on Henry Shue's work, ibid, the typology was developed by van Hoof, n. 106-8. It was embraced in the Limbur Principles on the developed by van Hoof, n. 15 above Covenant on Economic, Social and Cug rinciples on the Implementation of the Internationa (1987) 9 Human Rights Ouarterly 122. The typology was Doc E/CN.4/1987/17, Annex, repr. in tricht Guidelines on Violations of 120 . The typology was recently further elaborated in the MaasRights Quarterly 691 . or duties: to respect, protect, promote, and fulfil. ${ }^{22}$ The typology demonstrates that economic, social, and cultural rights share the same basic qualities as other human rights and, in particular, it indicates that they are equally capable of being incorporated into national and international legal systems. As the CESCR has emphasized, every ICESCR right has 'at least some significant justiciable dimensions' which, if violated, are appropriately resolved by courts. ${ }^{23}$ However, the Australian approach has remained mired in its own mythologies and, outside the anti-discrimination framework, resists even quasi-judicial approaches to incorporating economic and social rights into Australian law.

The specific legal obligation to implement the ICESCR is set out in Article 2(1) as follows:

Each State Party to the present Covenant undertakes to take steps, individually and through international assistance and cooperation, especially economic and technical, to the maximum of its available resources, with a view to achieving progressively the full realisation of the rights recognized in the present Covenant by all appropriate means, including particularly the adoption of legislative measures.

When considering implementation in a federated state like Australia, Article 28 is also important because it reiterates the general rule of international law that the Federal Government's international obligations are not limited by the division of powers between different levels of government: ${ }^{24}$ 'The provisions of the present Covenant shall extend to all parts of federal States without any limitations or exceptions.'

Therefore, the Federal Government must ensure that state ${ }^{25}$ governments play their part to the extent that implementation falls within their respective constitutional powers, which may be considerable. While the Federal Government theoretically has the constitutional power to legislate to implement its international treaty obligations under the external affairs power, ${ }^{26}$ in keeping with their general antipathy to incorporation, successive governments have instead relied on the cooperation of the states. ${ }^{27}$ Implementation that relies on

22 Briefly, the duty to respect refers to a state's obligation to refrain from acting in ways that would deprive people of their rights or impair their enjoyment of them, and is immediately applicable. The duty to protect requires states to act to ensure that third parties (private actors) do not violate human rights. The duty to promote includes ensuring human rights education at all levels of society. The duty to fulfil obliges states to take positive action to ensure that rights are realized or made accessible to
everyone.

${ }^{23}$ 'The domestic application of the Covenant: 03/12/98', CESCR General Comment 9, E/C.12/ 1998/24, 3 Dec. 1998, para 10, in Compilation of General Comments and General Recommendations Adopted by Human Rights Treaty Bodies, HRI/GEN/1/Rev.5, 26 Apr. 2001 (hereafter Compilation of General Comments).

24 Vienna Convention on the Law of Treaties 1969, Art 27: "[A] party may not invoke the provisions of its internal law as justification for its failure to perform a treaty.'

2s References to 'states' include the Northern Territory and the Australian Capital Territory.

26 See Koowarta v Bjelke-Petersen (1982) 153 CLR 168; Commonwealth v Tasmania (Tasmanian Dam case) (1983) 158 CLR 1.

27 D. Williams, 'Australia's Treaty-Making Processes: The Coalition's Reform Proposals', in P. Alston and M. Chan (eds.), Treaty-Making and Australia: Globalization Versus Sovereignty? (Sydney: Federation Press, 1995), 185 
intergovernmental consultation and cooperation will always be vulnerable to political exigencies, which will tend to be incompatible with human rights norms, in the absence of effective mechanisms of human rights accountability and a strong human rights culture. These absences are a major weakness in the Australia system of indirect implementation, as will be illustrated by the casestudy.

Article 11(1) of the ICESCR, largely repeating the text of Article 25 of the Universal Declaration of Human Rights $1948,{ }^{28}$ sets out the right to an adequate standard of living in the following terms:

The States Parties to the present Covenant recognize the right of everyone to an adequate standard of living for himself [sic] and his family, including adequate food, clothing and housing, and to the continuous improvement of living conditions. The States Parties will take appropriate steps to ensure the realisation of this right, recognising to this effect the essential importance of international cooperation based on free consent.

Under this article the Government commits itself to 'recognise' that everyone within its jurisdiction, not just male-headed households as suggested by the text, ${ }^{29}$ has the right to adequate food, clothing, and housing, and to living standards that are continuously improved. Fully implementing Article 11(1) involves recognizing that it depends on a complex interplay of economic and social conditions and the enjoyment of other rights, including many civil and political rights. ${ }^{30}$ Despite this complexity, the CESCR has adopted three General Comments, ${ }^{31}$ which identify specific obligations relating to Article $11(1)$ and help to make the task of implementation more tangible. ${ }^{32}$ In the first of these the CESCR rejects the view that the right to adequate housing is satisfied by the mere presence of a roof over one's head, insisting instead that it involves 'the right to live somewhere in security, peace and dignity'. ${ }^{33}$ The General

28 UN GA Res 217A(III), 10 Dec. 1948.

29 'The Right to Adequate Housing', CESCR General Comment No. 4 (6th Sess. 1991), para 6: "While the reference to "himself and his family" reflects assumptions as to gender roles and economic activity patterns commonly accepted in 1966 when the Covenant was adopted, the phrase cannot be read today as implying any limitations on the applicability of the right to individuals or to femaleheaded households or to other such groups.' See, further, 'The Right to Adequate Food', CESCR General Comment No. 12 (20th Sess. 1999), para 1, Compilation of General Comments, n. 23 above 30 CESCR General Comment No. 4, n. 29 above, para 9. See, further, L. Farha, 'Women and Housing', in K. D. Askin and D. M. Koenig (eds.), Women and International Human Rights Law, (Ardsley, NY: Transnational Publishers, 1999), 483, 494.

31 The purpose of General Comments is to consolidate the experience that has been gained from examining states' periodic reports and make it available to assist and encourage the further from mentation of the ICESCR by all states parties. See, further, 'Reporting by States Parties', General Comment No. 1 (1989), para 3, Compilation of General Comments $n$ General Comments provide authoritative interpretations of the Covenant's provisions, which Many important contributions to the normative development of the Covenant rishts. 32 CESCR General Comment No 4 development of the Coverar

Evictions', CESCR General Comment N, n. 29 above; 'The Right to Adequate Housing: Forced 23 above; and CESCR General Comment No 12 Sess. 1997), Compilation of General Comments, 3 CESCR General Commeral Comment No. 12, n. 29 above.

requirements of the concept of 'adequacy', including, para 7 . At para 8 the CESCR identifies various
Comment also notes that homelessness and inadequate housing are significant problems in some of the most economically developed countries. ${ }^{34}$

Appraising the Australian Government's compliance with its obligations under Article 11(1), in relation to homeless people, requires assessing the measures the Government has adopted to address homelessness against the four main requirements of Article 2(1). The first, that the Government must 'take steps' towards realizing the right, is an obligation of conduct. Although the wording falls short of requiring that the right to an adequate standard of living be 'guaranteed', it is a positive undertaking. Therefore, the Government cannot be inactive, or just refrain from taking steps that would result in an increase in homelessness, but must immediately act to adopt measures aimed at achieving the 'full realisation' of Article 11(1). ${ }^{35}$ The steps taken 'should be deliberate, concrete and targeted as clearly as possible towards meeting the obligations recognised in the Covenant'. ${ }^{36}$ Among the steps envisaged by the CESCR are adopting a national housing strategy, ${ }^{37}$ giving due priority to addressing the housing needs of disadvantaged groups, ${ }^{38}$ and effectively monitoring the full extent of homelessness and inadequate housing. ${ }^{39}$

The second requirement is that the steps taken must be 'with a view to achieving progressively the full realisation of the rights recognised'. Implicit in this wording is the acceptance that states parties may need some time to fully realize economic, social, and cultural rights. However, the CESCR has emphasized that the obligation requires movement 'as expeditiously and effectively as possible towards the goal [of full realisation]'. 40 Therefore, for example, the Government would be expected to achieve, over time, a decrease in the number of homeless people in Australia. Of particular importance is that the obligation does not allow any retrogressive measures, except in the narrowest of circumstances. The CESCR has cautioned that such measures 'would require the most careful consideration and would need to be fully justified by reference to the totality of rights provided for in the Covenant and in the context of the full use of the maximum available resources'. ${ }^{41}$ The CESCR has also stressed that there are immediately realizable aspects of every Covenant right, including the obligation to ensure non-discrimination in the enjoyment of all ICESCR rights, as provided for in Articles 2(2) and 3.42

The third requirement of Article 2(1) is that the Government take steps 'to the maximum of its available resources'. While resource distribution is primarily a political determination, states parties do not have complete discretion. The

34 Ibid., para 4.

35 P. Alston and G. Quinn, 'The Nature and Scope of States Parties' Obligations Under the International Covenant on Economic, Social and Cultural Rights', (1987) 9 Human Rights Quarterly 156.

36 'Article 2, para. 1: the nature of States parties obligations', CESCR General Comment No. 3 , para 2 (1990), Compilation of General Comments, n. 23 above.

${ }^{37}$ CESCR General Comment No. 4, n. 29 above, para 12.

39 Ibid., para 13.

41 Ibid. 42 Ibid., para 5. 
Covenant envisages that budget allocations are reviewable as against the country's 'real' resources, which obliges states parties to show that they have given adequate consideration to their obligations in the budget process. ${ }^{43}$ The CESCR has also taken the view that the obligation involves the satisfaction of a "min imum core' of each of the rights, which includes, inter alia, the provision of basic housing. ${ }^{44}$ In a developed state like Australia, the concept of a minimum core obligation is not a very useful yardstick, as the resources available should enable the Government to come very close to fully realizing the rights in the ICESCR 45

The fourth requirement is implementation by 'all appropriate means'. While Article 2(1) expresses a preference for legislative measures, other means are clearly acceptable. In taking a 'broad and flexible approach',46 the Covenant leaves considerable scope for states parties to determine the measures they adopt; it is the result of 'progressive movement towards' full realization that is of primary importance, rather than the means of its achievement. However, while the means will be appropriate if they produce the result of progressive realization, ${ }^{47}$ the CESCR is also of the view that 'the norms must be recognised in appropriate ways within the domestic legal order' ${ }^{48}$ Consequently, a failure to incorporate a Covenant right directly into the domestic legal system is not necessarily a violation of Article $2(1)$, but the state party would need to be able to justify its indirect measures in terms of their appropriateness. 49

Concomitant with the obligation to implement rights by all appropriate means is the obligation to provide appropriate mechanisms for remedying violations of ICESCR rights and ensuring governmental accountability. ${ }^{50}$ Therefore, the ICESCR will not be fully implemented in the absence of 'effective remedies' enabling individuals and groups to enforce the rights guaranteed in the ICESCR. ${ }^{51}$ In particular, the CESCR is concerned that states parties provide sufficient access to judicial remedies where the rights are capable of immediate application..$^{52}$ In relation to the right to adequate housing, the CESCR has said that many components of the right lend themselves to the provision of legal remedies, such as protecting against forced evictions, ${ }^{53}$ even to some extent in

43 Alston and Quinn, n. 35 above, 180

${ }_{44}^{4}$ CESCR General Comment No. 3, n. 36 above, para 10.

45 For consideration of how to make this assessment, see R. Robertson, 'Measuring State Compliance with the Obligation to Devote the "Maximum Available Resources" to Realizing Economic, Social and Cultural Rights', (1994) 16 Human Rights Quarterly 693.

${ }_{46}$ CESCR General Comment No. 9, n. 23 above, para 1.

47 Ibid., para 5. The CESCR has interpreted the use of the term 'appropriate' in Art 2(1) to require that 'the means used should be appropriate in the sense of producing results which are consistent with
the full discharge of its obligations under the Covenant'.

48 CESCR General Comment No. 9, n, 23 above, para 2. $\quad{ }_{49}^{49}$ Ibid., para 3.

$\begin{array}{ll}40 & \text { Ibid., para } 2 .\end{array}$

S2 CESCR General Comment No. 3, n. 36 above, para 5. The CESCR has emphasized the appropriateness of judicial remedies for some obligations, such as (but not limited to) those guaranteeing the non-discriminatory enjoyment of ICESCR rights. See CESCR General Comment No. 9 23 above, para 9.

S9 29 a n. 29 above, para 9 , whether by public or private persons or bodies. emergency housing situations. ${ }^{54}$ But the term 'effective remedy' is not limited to judicial remedies and the CESCR accepts that administrative remedies will often be appropriate. ${ }^{55}$ Thus, remedies may be provided by independent statutory bodies established by parliaments, such as ombuds offices and human rights commissions, like HREOC, or by other forms of alternative dispute resolution. In addition, remedies may be policy-based, such as developing a plan for implementation, establishing benchmarks and time-frames, or explicitly articulating human rights principles to guide programme development. Yet while a wide range of non-judicial measures can play an important role, their adequacy in providing effective remedies must be seriously questioned.

In sum, it is clear from the text of the ICESCR, and from the authoritative interpretations developed by the CESCR, that the obligation to implement the Covenant gives governments wide discretions to determine measures that are consistent with the particularities of their legal, political, and administrative systems. Remedies too may be very diverse, ranging from judicial enforcement to the setting of benchmarks against which the effectiveness of policies can be assessed. Article $2(1)$ balances the relationship between politics and law by forefronting government policy-making when it comes to determining the 'maximum available resources', while giving particular emphasis to legislative measures in implementation. As the case-study will show, one consequence of the Australian preference for indirect implementation and the traditional 'reluctance' about legal rights ${ }^{56}$ is a lack of effective remedies for violations of ICESCR rights. This casts doubt on Australia's present capacity to fulfil its international obligations, despite the Government's claim that it is 'fully committed to protecting each right guaranteed by the Covenant'. 57

THE CASE-STUDY: THE SUPPORTED ACCOMMODATION Assistance Program

The SAAP provides services and support to some of the most disadvantaged and marginalized people in Australia: the homeless population of elderly people, mainly men; women and children who are escaping domestic violence; unemployed and/or abused young people; and families living in poverty. ${ }^{58}$ Those supported by SAAP include Aborigines and Torres Strait Islanders ${ }^{59}$ and people

54 CESCR General Comment No. 4, n. 29 above, para 8(a).

55 In the case of administrative remedies, an effective remedy means one that is 'accessible, affordable, timely and effective'; CESCR General Comment No. 9, n. 23 above, para 9.

56 Charlesworth, n. 12 above. 57 Third Periodic Report: Australia, 9 above, para 7. 56 Charlesworth, n. 12 above. S7 Third Periodic Report: Australia, n. 9 above, para 7. 58 Australian Institute of Health and Welfare, SAAP National Data Collection Annual Report 2000-01 (Canberra: AIHW, 2001), estimates SAAP services supported 91,200 clients during the twelve-month period. This figure does not include accompanying children. The main reasons for seeking assistance were domestic violence ( 23 per cent), eviction or end of previous accommodation
(11 per cent), relationship breakdown ( 10 per cent), and financial difficulty (10 per cent).

s9 Ibid. During 2000-1 Aborigines and Torres Strait Islanders comprised 16 per cent of SAAP clients, yet their representation in the population is under 2 per cent. 
from many different ethnic backgrounds including, increasingly, asylum-seekers awaiting determination of their immigrant status. The programme is jointly funded by the federal and state governments and administered by the states within a legislated national policy framework. It provides financial assistance to non-government organizations and local government authorities that provide a range of supported accommodation and related support services to people who are temporarily or permanently homeless. ${ }^{60}$ It is the first coordinated national approach to addressing the complex and multifaceted problems of homelessness in Australia. ${ }^{61}$ As the Government reported to the CESCR in its 1990-7 periodic report, SAAP 'is one of the primary Government responses to homelessness' and, as such, it constitutes an important measure towards implementing Article 11(1). 62

The SAAP is given effect through Commonwealth-state Agreements of five years' duration. The objective of the programme, identified in the first Agreement 1985-9 (SAAP I), is to assist those who need housing support 'to move towards independent living, where possible and appropriate'. ${ }^{63}$ To this end, the programme aims to fund services that encourage self-help in a noninstitutionalized setting. ${ }^{64}$ While SAAP's significance in the context of International Youth Year (1985) and the International Year of Shelter for the Homeless (1987) was noted in the Second Reading Speech, no mention was made of its relationship to Australia's international human rights obligations. 65

However, successive SAAP agreements have paid increasing attention to recognizing the 'rights' of the homeless people who use SAAP services. The second Agreement 1990-4 (SAAP II) emphasized the importance of providing support that recognizes clients' independence, dignity, and self-esteem, ${ }^{66}$ and aimed to 'establish a framework for the protection of the rights of users of services' ${ }^{67}$ Specifically, the Agreement required the development of principles and strategies for the protection of user rights, and the establishment of internal grievance procedures within each SAAP-funded service and external review procedures 'by government officials or other independent review', ${ }^{68}$ The SAAP II also indicated that user rights 'may include such matters as participation in decision making,

${ }^{60}$ Second Reading Speech, Supported Accommodation Assistance Bill 1985, House of Representatives, 27 Mar. 1985, Hansard 1020.

61 The SAAP was preceded by the Homeless Persons Assistance Act 1974 (Cth), which was the first legislation to recognize that the provision of assistance to homess national government.

62 Third Periodic Report: Australia, n. 9 above, para 219.

63 Supported Accommodation Assistance Act 1985 (Cth) (SAAP I), Schedule, para 6.

64 Minister for Community Services, Second Reading Speech, n. 60 above.
66 Supported Accommodation Assistance Act 1989 (Cth) (SAAP II), Schedule 1, Form of Agree ment. The net A ment. The new Agreement was informed by the report of the National SAAP Evaluation Steering Assistance Promes Assistance Program', prepared by Colleen Chesterman (1988).

principle, and explicitly noted that sAAP II also emphasized non-discrimination as a programme principle, and explicitly noted that services should be designed to provide equitable access for

Aboriginal people and people from non-English-speaking backgrounds; see para $6(1)(d)$
68 Ibid., clause 15 . information about available assistance, and security and freedom from abuse', 69 making it clear that user rights were internal to SAAP services, as between users and service providers, rather than rights that could be exercised against the state with respect to the standard of living of service users.

Five years later the national evaluation of SAAP II found that only 'some progress' had been made in the development and implementation of user rights policies, in the process of developing SAAP minimum service Standards. ${ }^{70}$ The evaluation found variations between states in the scope of the Standards and in their progress towards implementation. ${ }^{71}$ It recommended that the ongoing implementation of a national user rights policy be given a high priority and also that nationally consistent minimum standards of service delivery be developed and incorporated into funding agreements with SAAP providers. ${ }^{72} \mathrm{With}$ regard to internal grievance procedures, the evaluation found that most states were still in the process of implementation. Even more troubling, external complaints and appeals mechanisms were only in place in New South Wales, ${ }^{73}$ where a Community Services Commission was established in 1994 to consider complaints from users of any community service, including those funded by SAAP. ${ }^{74}$ The evaluation noted the particular difficulties of implementing user rights policies in SAAP 'where many users have low self esteem, limited coping skills and often use services for relatively short periods'.$^{75}$ It also noted that some service providers were concerned 'about the possible consequences for them (and indeed for other SAAP users) of the irresponsible exercise of user rights policies by individual clients'. ${ }^{76}$ Understanding rights as encouraging and condoning 'trouble-making', in this way, is one commonly heard expression of the Australian 'reluctance' about rights. The national evaluation of SAAP II also found that 'the most intractable problem facing SAAP is the lack of suitable, affordable housing for SAAP users when they leave SAAP services' ${ }^{77}$ Consequently, the primary objective, to provide transitional support and move clients as quickly as possible to independent living, was thwarted by a lack of 'exit points', ${ }^{78}$ and

69 Ibid., para 15(a).

70 National SAAP Evaluation Steering Committee, Moving Forward: Report of the National Evaluation of $S A A P$ propared for the Steering Committee by Mary Lindsay (1993) 71

71 Ibid 73-4.

${ }_{33}$ External complaints mechanisms were also available, to a very limited extent, in the Australian 73 External complaints mechanisms were also available, to a very limited extent, in the Australian
Capital Territory, with the establishment of the Office of the Community Advocate in 1992 . However, the role of the Community Advocate is restricted to protecing the rights of children under 18, adults with a disability, people with a mental dysfunction and involved in the criminal justice system, and people with a physical, mental, psychological, or intellectual condition which necessitates protection from abuse, neglect, or exploitation, which would by no means cover all SAAP clients. See Moving Forward, $\mathbf{n} .70$ above, 72

74 The legislation establishing the Community Services Commission was the Community Services (Complaints, Appeals and Monitoring) Act 1993 (NSW), since renamed the Community Services (Complaints, Reviews and Monitoring) Act. Priority is given to vulnerable groups, which are identified as children and young people, people with disabilities, consumers of home care services, and consumers of SAAP services. Of the 1,106 complaints finalized by the Commission in the year 2000-1, only 3 per cent involved SAAP services. See $\langle h t t p: / / w w w . c s c . n s w . g o v . a u>$.

${ }_{75}$ Moving Forward, n. 70 above, $71 . \quad 76$ Ibid. 72.

78 R. Fopp, 'No Where to Go: An Analysis of the Supported Accommodation Assistance Program', (1996) 31/2 Australian Journal of Social Issues 209, 212. 
some SAAP users were forced to 'remain in SAAP services when their need for support has passed'. ${ }^{79}$ This, in turn, led to the high turn-away rate of potentia SAAP users, exacerbating their housing crisis.

It was not until the third Agreement $1995-9$ (SAAP III) ${ }^{80}$ that an explicit connection with Australia's international human rights obligations was made in the legislation. The preamble to the Act referred to Australia's recognition of 'international standards for the protection of universal human rights and fundamental freedoms' as one of the considerations that had informed the legislation. Six international instruments were listed, with the ICESCR first among them. ${ }^{81}$ In addition, the preamble recognized the need to 'redress social inequalities and to achieve a reduction in poverty' and declared the right of homeless people 'to an equitable share of the community's resources' ${ }^{82}$ The preamble also stated that the Federal Government intended to work cooperatively with the state governments to ensure that the 'universal human rights [of SAAP clients] are not prejudiced by the manner in which services are provided to them' ${ }^{83}$ These commitments seemed to promise, in addition to user rights, the recognition of a broader range of rights, involving substantive claims on community resources to ensure an adequate standard of living for homeless people. However, the minister in his Second Reading Speech made it clear that 'the rights of people who are homeless, to housing and to the other essential elements of a decent quality of life' would be realized by paying more attention to linking people to a range of other services, thereby 'maximising people's chances to participate', ${ }^{84}$ rather than by guaranteeing substantive rights. While the need to improve the internal protection of user rights within SAAP services is an important goal, ${ }^{85}$ rights limited to the service delivery arena do nothing to address the problem of the shortage of adequate housing options. ${ }^{86}$

Although guided by national principles, ${ }^{87}$ the responsibility for developing service standards and practices remained with the state governments, paving the

79 Moving Forward, n. 70 above, 107

81 Ibid., Pred Accommodation Assistance Act 1994 (Cth) (SAAP III).

the Elimination of All Forms of Racial Discrimination 1965, the were the International Convention on Forms of Discrimination Against Women 1979, the Conv, the Convention on the Elimination of All Forms of Discrimination Against Women 1979, the Convention on the Rights of the Child 1989, the Universal Declaration of Human Rights 1948, and the Declaration on the Elimination of Violence
Against Women 1994. Against Women 1994.

82 SAAP III, n. 80 above, Preamble, paras 2 and 5.

${ }_{84}$ Second Reading Speech, House of Representatives, Hansard, ${ }^{83}$ Ibid., para 7.

${ }^{85}$ SAAP III, n. 80 above, s 5(4)(f) states: 'SAAP is to safeguard clients' rights and deal with clients' responsibilities through measures including, but not limited to (i) the development of grievance and appeals procedures; and (ii) the development of charters of clients' rights and responsibilities' ${ }^{86}$ CESCR General Comment No. 4, n. 29 above, para 8, defines ade and responsibilities. security of tenure, availability of services infrastructure, affordability adequate housing as including tion, and cultural adequacy.

87 B. Grigson, 'The Supported Accommodation Assistance Program-Client Rights and Participa-
tion', (1998) 11/3 Parity 5 . The tion', (1998) 11/3 Parity 5 . The principles are: to ensure user rights, participation, and choice, ation, privacy, confidentiality and access to personal inf, access to services, information and consultcoordinated, planned, and reliable service delivery, and responsiventient and effective management, way for the development of seven different sets of standards. In Victoria the SAAP Standards of Service Delivery ${ }^{88}$ identified five standards relating to the service environment ${ }^{89}$ and seven relating to user rights. ${ }^{90}$ Responsibility for implementing the Standards is devolved further to the nine regions in Victoria. At this level they are incorporated into the funding agreements, which are negotiated between individual SAAP services and regional SAAP advisers, who also provide advice to services on the implementation of the Standards. In Victoria all 330 SAAP services commit, through their funding negotiations, to implement the Victorian SAAP Standards and to have in place an internal grievance procedure. These commitments are then further translated into service practices within each individual service, usually in the form of internal policies and procedures manuals.

In order to make an assessment of the progress towards protecting the rights of service users, the two workers at the Support and Accommodation Rights Service (SARS) were interviewed in Melbourne on 17 July 2001.91 The SARS, which opened in January 1994, is funded by SAAP under the auspices of the Council to Homeless Persons, a peak body to many of the SAAP-funded services in Victoria. The SARS offers an advocacy service for SAAP clients, or potential SAAP clients, when they come into conflict with a service. ${ }^{92}$ According to SARS publicity about its service, those seeking or using SAAP services have rights

${ }_{88}$ Health and Community Services (H \& CS), SAAP Standards of Service Delivery (Melbourne: H \& CS, 1994); H \& CS, SAAP Standards Implementation Guide, researched and written by David Aarons (Melbourne: H \& CS, 1994).

${ }^{89}$ Included in this category are: a service culture sensitive to the problems of homelessness, domestic and family violence, and personal crisis; a non-institutionalized, safe, and appropriate physical setting which provides for individual needs; an environment that is healthy and safe for employees, volunteers, and service users; suitably skilled and/or experienced staff who receive ongoing training; and ongoing supervision and support for staff from management.

90 The standards relating to user rights were: autonomous decision-making, assessment, and referral, service information, privacy and confidentiality, non-threatening environment, support and referral, service information, privacy and confidentiality, non-threatening environment, support and participation in service management. The standards are augmented by other policies including Department of Human Services Victoria (HSV), information Privacy Principles (Melbourne: HSV, 1999), which sets out twelve principles to guide the collection of personal information by HSV and SAAP service providers, accompanied by extensive explanatory notes; and HSV, Quality Jan. 1999).

91 Interview with Paula Marsh and Andrea Stanlake, Supported Accommodation Rights Service, 91 Interview with Paula Marsh and Andrea Stanlake, Supported Accommodation Rights
Melbourne (SARS), 17 July 2001 (hereafter SARS Interview) (copy on file with author).

$92 \mathrm{G}$. Wettenhall, M. Howie, and A. Howie, What's in a Name? How the SAAP Advocacy Service $92 \mathrm{G}$. Wettenhall, M. Howie, and A. Howie, What's in a Name? How the SAAP Advocacy Service
Became the Supported Accommodation and Rights Service (Melbourne: Waalima Publications, Mar. Became the Supported Accommodation and Rights Service (Melbourne: Waalima Publications, Mar.
1995 ), 9. Interestingly, the SARS was initially called the SAAP Advocacy Service, but the name was changed in 1995, as recommended by consultants, who found that almost none of the forty-six service users in their study knew what either 'SAAP' or 'advocacy' meant. While they found that younger service users understood the concept of 'rights' and felt comfortable with it, they found that older people preferred a 'softly softly' approach. While they concluded that in the longer term it may be necessary to provide different information for young and old service users, they opted for the use of the term 'rights' in the name of the service because of the particular vulnerability of young people. The view of the older service users would appear to reflect the traditional suspicion about rights discourse in popular Australian culture. 
to freedom, privacy and safety...t to have whatever is necessary so that you are not hungry, are not cold, have a house, and are looked after when you are ill... to be protected if someone wants to force you to change the way you are, what you think or write... nobody can enter your house without a reason... [to] be protected in the same way, everywhere and like everyone else. ${ }^{93}$

The source of these rights is identified as the Universal Declaration of Human Rights, but this is misleading. The reality is that the SAAP Standards define the rights that are to be enjoyed by SAAP users, and SARS advocacy is limited to the Standards. There is no right to 'have a house' in the Standards and there is no guarantee that a homeless person will have access to a SAAP service. Further, the procedures for conflict resolution are defined by each service's internal grievance procedure, which may also restrict the extent of advocacy that is possible. ${ }^{94}$

The most common complaints that SARS receives are about being evicted from a SAAP service or the withdrawal or denial of a service. ${ }^{95}$ If the client is being evicted for behaviour that the client knew would lead to eviction, there is really nothing that SARS can do to assist them. ${ }^{96}$ This raises the thorny issue of the relationship between user rights and responsibilities, which is also related to the fear that rights will be exercised irresponsibly. The SAAP Standards require that within twenty-four hours of being in the service, a service user must be provided with information about user rights and responsibilities. ${ }^{97}$ According to SARS, the list of responsibilities (often merged with service rules) is usually much longer and more involved than the list of rights. ${ }^{98}$ It is a common occurrence that a service provider withdraws rights because responsibilities are not fulfilled or rules are broken. One example given by SARS is that services users are frequently evicted because of 'violence', yet there are many unresolved issues about what constitutes violence, and middle-class workers can have a very different view from, for example, a young woman who has been subjected to violence all her life. ${ }^{99}$ In the event of eviction from a SAAP service, it is not uncommon, in the experience of SARS, that the service provider will also refuse to refer the evicted person on to another service; the view is taken that 'well if you can't be responsible, then I'm not going to give you a right'. ${ }^{100}$

The SARS has also found that many workers in the sector have never seen the SAAP Standards and do not know that they are binding. While workers have 'dutifully' read the service's policy manual, they are often not aware that it is based on the Standards, 'which usually sit on the manager's bookshelf, in their office'. ${ }^{101}$ The service policies develop 'like a game of whispers', starting off consistent with the SAAP Standards but changing, over time, as the service

93 Support and Accommodation Rights Service, pamphlet, n.d., available from <http:// www.chp.org.au/sars>.

94 SARS Interview, n. 91 above, 10.

95 Ibid. 28. Other common complaints to SARS have been about lack of confidentiality and lack of support.

96 Ibid. 24-5.

97 SAAP Standards, n. 88 above, 8. changes direction or faces different challenges. ${ }^{102}$ Further, SARS has found that, on occasion, when asked about their internal grievance procedure, a worker will say they 'just can't find it', despite the requirement in the Standards that they provide a copy to new clients within twenty-four hours. ${ }^{103}$

During the 1999/2000 financial year SARS assisted 350 service users who required information, referral, and advice, and provided advocacy for more than seventy others who entered into formal grievance procedures with SAAP services. Needless to say, despite the best efforts of the two SARS workers, it is impossible for such a small unit to provide adequately a state-wide advocacy and advice service for over 27,000 service users annually with over 12,000 accompanying children, ${ }^{104}$ let alone for the overwhelming number of people whose requests for assistance cannot be met by SAAP. ${ }^{105}$ Further, SARS is by definition concerned only with advocacy for clients in processes that are internal to services. SARS does not play a mediation or adjudicative role, nor does it have any investigative or community visiting powers. If a dispute remains unresolved, the only option is to take it to the regional SAAP adviser, which, in the experience of SARS, has not been helpful. ${ }^{106}$

In sum, there is no mechanism for effectively monitoring services' compliance with the SAAP Standards or the operation of internal grievance procedures. Apart from occasional internal scrutiny when an individual client makes a complaint, there is only the annual process of renewing Funding Agreements with the regional SAAP adviser, which is a highly formal process that is usually satisfied by the mere existence of a user rights policy and an internal grievance procedure. ${ }^{107}$ It does not matter, for example, whether the internal grievance procedure is 'a little quarter page diagram' or 'sixteen pages of legalese', as the form of the procedure is at the discretion of the service provider. ${ }^{108}$ Further, except in New South Wales, there is no external, independent review or appeals mechanism. The lack of accountability, especially in the context of devolution, leads to a lack of uniformity in the 'rights' ostensibly enjoyed by service users, divergent interpretations of those rights, confusion about the relationship between rights and responsibilities, and uneven implementation. This leads to a great deal of confusion for clients and does not engender the respect for user rights that the SAAP programme has so keenly promoted at the national policy level.

This brings us to the heart of the Australian debate about rights and the best way to implement them. The SARS workers preferred a non-judicial approach. They thought the 'legal' approach was problematic because it did not leave room

102 Ibid. 10-11. 103 Ibid. 5.

104 Department of Human Services (Victoria), Review of Services, Programs and Directions in SAAP III (Melbourne: KPMG Consulting, 1998), records statistics from the SAAP National Data Collection Agency, 1997-8, for Victoria. They indicate that 10,924 men and 16,141 women were SAAP clients during that period. These numbers exclude clients whose sex was unknown, and also exclude any dependent children of SAAP clients.

105 Ibid. 37. Unmet requests for assistance in Victoria in 1997-8 numbered over 45,000.

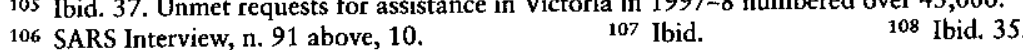


for 'more ethical concerns'109 and worked against the approach of 'honestly talking things through' because workers would take the view that 'I'm not admitting anything if I think you're going to have me in court in the witness box.' 110 They thought that, in the event of extreme abuse, existing civil and criminal laws were sufficient. The SARS workers saw the solution to the present lack of accountability lying in a scheme of independent investigators able to follow up complaints by being able to 'walk into that service, check it out, see what was really happening, make a report, make a finding and then tell the Department "You need to act... on this, because while they might have the policies, they're actually not abiding by them." '111 They also liked the idea of a 'community visitor' scheme that would involve unscheduled visits to 'check out with the clients how it's going and what their views of the service are' and report on their findings 'in a way that's a bit anonymous (for the client) and actually might have some impact'. 112 While they observed that 'the services would go nuts', they thought that investigation by a disinterested party would fill the current gap in service accountability. ${ }^{113}$

The Victorian evaluation of SAAP III was also critical of the limited capacity of the Funding Agreement process to monitor adherence to the SAAP Standards. It suggested a range of strategies that would provide incentives for best practice and disincentives for poor practice and recommended the establishment of more rigorous monitoring and review mechanisms both within services and externally through accreditation and/or auditing processes. ${ }^{114}$ Yet there were no new developments in the SAAP IV Agreements that addressed the issues of accountability any differently. ${ }^{115}$ Further, while the programme remains committed to the improvement of the quality of SAAP service delivery, the lack of any guarantee of access to SAAP services for large numbers of eligible homeless people also remains unaddressed, and the critical shortage of adequate long-term housing options for those SAAP clients who no longer need supported accommodation remains outside the scope of SAAP.

\section{CAN INDIRECT MEASURES OF IMPLEMENTATION FULFIL}

$$
\text { AUSTRALIA'S INTERNATIONAL OBLIGATIONS? }
$$

As a coordinated national response to homelessness, SAAP provides a means for the Federal Government to fulfil some of its implementation obligations

109 The view that 'rights' are antithetical to ethical values like happiness and empathy is, as Campbell argues, a common assumption in political ideology. See Campbell, $\mathrm{n}$. 10 above, 198, citing C. Sypnowitch, The Concept of Socialist Law (New York: Oxford University Press, 1990).
${ }_{113}^{110}$ SARS Interview, n. 91 above, 37 111 Ibid. 38.
113 Ibid 114 Ibid. 8. Commonwealth and each state government, under the provisions of the Supported Accommodation Assistance Act 1994 (Cth) (SAAP III) and according to the Memorandum of Understanding for the SAAP Program 2000-05 endorsed in principle by the Commonwealth and state governments 5 Aug. 1999, and thereafter signed by the individual states on various dates. under the ICESCR, particularly aspects of its obligation to recognize the right of everyone to an adequate standard of living (Article 11(1)). Successive SAAP Agreements have strengthened the programme's emphasis on providing support towards independent living, on service user rights, and on the establishment of grievance procedures within services, drawing increasingly on international human rights standards for guidance. The programme clearly aims to empower people who are among the most vulnerable and disadvantaged in the Australian community by promoting the core human rights principles of dignity, autonomy, and participation. It provides an illustration of how international human rights instruments are contributing a new language of rights, and a framework for expressions of human dignity, to the Australian political and legal landscapes. While SAAP is only one of a complex range of measures required to fully implement Article $11(1)$, it nevertheless provides a useful case-study of the benefits and problems associated with indirect forms of implementation.

In order to assess the extent to which SAAP implements Article 11(1), we need to consider the requirements of Article 2(1) in light of the case-study. The first of these, the requirement that the Government 'take steps' towards realizing the right, has no doubt been satisfied. The Government has not been inactive in addressing homelessness, and the development of SAAP is a positive measure towards that end. The programme seeks to give 'due priority' to those who are living in unfavourable conditions, ${ }^{116}$ and is 'deliberate, concrete and targeted' towards the primary goal of supporting clients to attain independent living, which would realize at least some aspects of the right to an adequate standard of living. Further, the SAAP definition of 'homelessness' is broadly framed as 'inadequate access to safe and secure housing', ${ }^{117}$ which is consistent with the CESCR's view that 'adequate housing... should be seen as the right to live somewhere in security, peace and dignity'.118 Nevertheless, the case-study reveals that other 'steps' need to be taken, like ensuring that there are more long-term housing options available to SAAP clients when they are ready to leave SAAP services. Such steps would include, as strongly recommended by the CESCR, that the Federal Government develop a national housing strategy that

116 CESCR General Comment No. 4, n. 29 above, para 11.

117 SAAP III, n. 80 above, $\mathrm{s} 4(2)$ states:

For the purposes of this Act, a person is taken to have inadequate access to safe and secure housing if the only housing to which the person has access:

(a) damages, or is likely to damage, the person's health; or

(b) threatens the person's safety; or

(c) marginalizes the person through failing to provide access to:

(i) adequate personal amenities; or

(ii) the economic and social supports that a home normally affords; or places the person in circumstances which threaten or adversely affect the adequacy, safety, security and affordability of that housing.

118 CESCR General Comment No. 4, n. 29 above, para 7. 
is consistent with Australia's obligations under the ICESCR, and ensure that state and territory governments do likewise. ${ }^{119}$

The second requirement of Article $2(1)$ is to achieve 'progressively' the full realization of the recognized right, as 'expeditiously and effectively as possible'. In the context of SAAP, this could mean achieving a reduction in the number of people needing SAAP services, a decrease in the number of people turned away because SAAP services are full, and/or a decrease in the number of SAAP clients forced to remain in SAAP beyond when their need for support has passed. Yet despite the five-yearly reviews of the programme that assess its progress towards fulfilling national objectives, and annual national data collection that should enable new problems and trends to be identified and addressed quickly, progress has not been achieved according to any of these measures. ${ }^{120}$ The CESCR drew attention to this issue after its initial review of Australia's last periodic report, asking why the Government had failed to address the rising number of homeless people and requesting that comparative statistics covering the previous five years be provided on the number of people who are homeless and the number who have access to public housing. ${ }^{121}$ The CESCR also requested information on the access of homeless people, among others, to adequate food. ${ }^{122}$ These requests indicate that the Government provided inadequate information for the monitoring purposes of the CESCR, indicating a failure to fulfil its reporting obligations, and leaving open the possibility that there was in fact a regressive movement, which the CESCR has said would need to be 'fully justified'.

The third requirement of Article 2(1) is that the Government devote the 'maximum of its available resources' towards progressively realizing ICESCR rights. As Australia's economy grew consistently through the 1990 s, anything less than full enjoyment of an adequate standard of living raises fundamental questions about resource allocation. While the Government has progressively increased its expenditure on SAAP, ${ }^{123}$ there is clearly a serious shortage of long-term housing options of the sort that are required by those who use SAAP services; low-rental housing, suited to a range of household configurations, located close to services and public transport. This is despite the Commonwealth-State Housing Agreement, which aims to 'assist every Australian with access to housing that is affordable, secure and appropriate to his or her needs' and a Rent Assistance Program administered through the social

119 Concluding Observations of the Committee on Economic, Social and Cultural Rights: Australia. 01/09/2000, E/C.12/1/Add.50, 1 Sept. 2001, para 34.

120 SAAP National Data Collection 2000-1, n. 58 above, 59 . The data collected shows that in 2000-1 SAAP services supported an estimated 91,200 clients, which was an increase over the previous year's estimate of 90,000 , although this was a decrease from the 1997-8 figure of 94,100 . See $<$ http:// www.aihw.gov.au/publications/hou/saapndcar 00-01>

121 List of Issues: Australia. 23/05/2000, E/C.12/Q/AUSTRAL/1, 23 May 2000, para 25.

122 Ibid., para 28.

${ }^{123}$ Recurrent expenditure for SAAP increased by 22 per cent in the five years from 1996-7 $\$ 219.8$ million) to 2000-1 ( $\$ 268.5$ million), which in real terms amounts to an increase of 10 per cent; SAAP National Data Collection 2000-01, n. 58 above, 59. security system. ${ }^{124}$ The failure of the Government to provide the CESCR with comparative statistics showing expenditure on public housing over the previous five years ${ }^{125}$ also suggests that it had reason to avoid scrutiny of the level of resources it had devoted to low-income housing. ${ }^{126}$

The fourth requirement, which is the primary focus of my inquiry, is that the Government take 'appropriate' measures in the sense that they produce the result of progressive realization. The ICESCR clearly places emphasis on legislative measures, and the CESCR has said that a state party would need to justify nonlegislative (indirect) measures in terms of appropriateness. There are many questions associated with the adequacy of the legislative measures that have been adopted by Australian governments, ${ }^{127}$ which directly implement some incidents of Article 11(1) by prohibiting discrimination by landlords and protecting landlord-tenant rights and obligations, but they must be put aside to maintain my focus on indirect implementation. There are two concomitan obligations involved in taking appropriate implementation measures, which apply to indirect as well as direct measures: first, the obligation to recognize the right in the most appropriate form; and secondly, the obligation to provide mechanisms for remedying or redressing violations of the right.

With respect to the first of these obligations, the SAAP legislation provides for the identification and protection of the rights of SAAP clients as service users, which is understood as a way of assisting them towards independent living. User rights are not 'legal' rights, which entail a correlative and enforceable legal duty that they be respected or enjoyed. Nor are they 'human rights' in the sense of being inherent. Although informed in a general way by human rights principles, user rights are defined by policy processes at the state level, implemented through SAAP Funding Agreements, and enjoyed by service users as the result of an unenforceable 'contract' with the service provider that specifies rights in the context of user responsibilities. Conditioning the enjoyment of user rights on the performance of responsibilities is consistent with the Federal Government's embrace of 'mutual obligation' as the cornerstone of its welfare policies, in its move away from welfare 'entitlements' ${ }^{128}$ Under this policy, the Government ostensibly provides basic necessities, such as income support and job-search

124 Third Periodic Report: Australia, n. 9 above, paras 217-18.

125 List of Issues, n. 121 above, para 25

126 In fact, Australian governments over the past decade have decreased expenditure on public housing while increasing expenditure on rental subsidies in the private rental market. This move towards greater reliance on the private market has failed to deliver affordable housing to the poores Australian households, who are spending a mean of 66 per cent of their income on housing. See Australian Social and Economic Rights Project (ASERP), Australia's Compliance with the UN Covenant on Economic, Social and Cultural Rights: Community Perspectives, submission to the UN Committee on Economic, Social and Cultural Rights (Melbourne: Victorian Council of Social Service, Apr. 2000), 40-1.

127 Ibid. 39 and 41 . Concerns include reports of widespread discrimination and the lack of minimum housing standards in the private rental market.

128 J. Newman, 'The Future of Welfare in the 21st Century', National Press Club, 29 Sept. 1999, Canberra. See <http://www.facs.gov.au/internet/>. 
assistance for unemployed people, in exchange for undertakings that they engage in various activities aimed at increasing employability. Access to basic needs is denied, as in the SARS example, ${ }^{129}$ if the obligations are not met, without any reference to the capacity of the person to fulfil the obligation or to human rights principles. Such an approach to 'rights' is a thinly veiled exercise in coercive social control of those who are dependent on the community to provide basic social and economic goods. ${ }^{130}$ Although detailed discussion of the policy of 'mutual obligation' is beyond the scope of this chapter, it appears to be inconsistent with Australia's international human rights obligations, and its influence on the conditionality of user rights in SAAP services may violate the ICESCR.

'The rights available to SAAP clients are more aptly described as 'privileges' in the Hohfeldian sense of being available to the rights-holder on a contingent basis rather than as a legal entitlement. ${ }^{131}$ Unlike legal rights, which are referred to as 'claim rights' by Hohfeld, ${ }^{132}$ there is no express legal obligation on the state to honour 'privileges'. ${ }^{133}$ Indeed, the privatization of many services that were previously provided directly by the government has eroded the limited legal protection of welfare privileges previously provided by administrative law, because administrative review does not extend to 'contracts' between nongovernmental case managers and clients. ${ }^{134}$ Only the direct implementation of Article $11(1)$ would create claim rights, like those identified in the SARS publicity, to have 'whatever is necessary so that you are not hungry, are not cold, have a house, and are looked after when you are ill'. Further, only direct incorporation would give legal force to the 'right' of homeless people to an equitable share of the community's resources, referred to in the preamble to the SAAP III legislation, and create a cause of action in relation to the lack of 'exit points' for SAAP clients. As a privilege, enjoyment of the right to an adequate standard of living is solely dependent on political processes to determine its scope.

The appropriateness of recognizing an ICESCR right in the form of a privilege depends on fulfilling the second obligation associated with implementation, which is to ensure that there are effective 'remedies' in the event of a violation and independent mechanisms for ensuring government accountability. ${ }^{135}$

129 See discussion in text at n. 100 above.

130 P. L. Kinnear, 'Mutual Obligation: A Reasonable Policy?', Paper presented at the National Social Policy Conference, University of New South Wales, 4-6 July 2001 (copy on file with author). 131 W. N. Hohfeld, Fundamental Legal Conceptions as Applied in Judicial Reasoningor) W. W. Cook (New Haven: Yale University Press, 1919), 38-9.

132 Ibid. $36-8$.

133 This was confirmed by a single judge of the High Court in Green $\nu$ Daniels (1997) 51 ALJR 463. Stephen J found that unemployment benefits provided through the Social Securities Act 1947 (Cth) were 'no more than a gratuity', which was not enforceable at law See, further. P. Bailey 'The (Cth) an Adequate Standard of Living: New Issues for Australian Law', (1997) 4 . Bustralian Jo Right to Human Rights 25.

134 T. Carney and G. Ramia, 'From Citizenship to Contractualism: The Transition from Unemployment Benefits to Employment Services in Australia', (1999) 6 Australian Journal of Administrative Law 117.

${ }^{135}$ See, further, D. Otto and D. Wiseman, "In Search of "Effective Remedies": Applying the International Covenant on Economic, Social and Cultural Rights to Australia', (2001) 7 Australian journal of Human Rights 5 .
Remedies and accountability mechanisms can be very diverse and are by no means limited to the judicial sphere. In SAAP the non-judicial remedial apparatus designed to protect user rights (privileges) consists of internal grievance procedures, appeals to regional SAAP advisers, and, in theory except in New South Wales, independent external review. Given the vulnerability of SAAP clients, and the real possibility of eviction if a dispute is unresolved, the absence of comprehensive, independent, and publicly accountable external review mechanisms is a serious shortcoming of the SAAP scheme. The operation of such mechanisms would seem to be indispensable to ensuring effective remedies for individual service users, in the event that privileges are denied in a way that is inconsistent with the programme's policy and/or its legislated aims. Further, external review mechanisms could serve the related functions of raising broader human rights concerns and drawing attention to systemic problems that may require changes in policy or resource allocation, like the shortage of housing options for people on low incomes.

In the absence of the mechanisms envisaged in the SAAP legislation, the options for seeking an individual remedy are few indeed. There is limited recourse to HREOC, which is only empowered to reach a conciliated settlement of human rights complaints and, in any event, is confined to a definition of 'human rights' that does not include the ICESCR. The Ombudsman (sic), whose powers of review are broadly framed so as to cover human rights concerns in a general way, ${ }^{136}$ is similarly limited to the review of prescribed public authorities. In any event, generic options for administrative review are limited in their capacity to protect the rights of disadvantaged and marginalized groups, such as homeless people, because of formality and costs. Finally, there is the 'remedy' of democratic politics, which is also unlikely to be effective for groups who exercise little political power. ${ }^{137}$ This conclusion highlights the present importance of the ability to seek a remedy from an international body, particularly for disadvantaged Australians, once domestic options have been exhausted. Even though the 'views' of an international human rights treaty committee are not binding, and thus any governmental response to their views will also rely on political processes, at least such avenues provide independent review and the possibility of engaging the world community in shaming the Government into action. ${ }^{138}$ While there is, as yet, no individual complaints mechanism attached to the ICESCR, there is some scope for complaints about violations of economic and social rights to be considered by other treaty

136 J. McMillan and N. Williams, 'Administrative Law and Human Rights', in D. Kinley (ed.), Human Rights in Australian Law (Sydney: Federation Press, 1998), 63, 66. See the Ombudsman Act Human Rights in Australian Law (Sydney: Federation Press, 1998), 63, 66. See the Ombudsman Act
1976 (Cth), s 15. All Australian states and territories have legislated for an office to perform similar 1976 (Cth), s 15. All Australian states and territories have
functions to those of the Commonwealth Ombudsman.

${ }_{137} \mathrm{~K}$. Walker, 'Who's the Boss? The Judiciary, the Executive, the Parliament and the Protection of ${ }^{137}$ K. Walker, 'Who's the Boss? The Judiciary, the Executive, the Parlian
Human Rights', (1995) 25 Western Australian Law Review 238, 250.

138 The Government's response to the Human Rights Committee's views in Toonen v Australia,
Tuman Right', (1995) 25 Wester Austian Law Review 238, 250. 138 The Government's response to the Human Rights Committee's views in Toonen $v$ Australia,
CCPR/C/S0/D/488/1992, provides an example of the mixed success of this strategy. See W. Morgan, $\mathrm{CCPR} / \mathrm{C} / \mathrm{S} 0 / \mathrm{D} / 488 / 1992$, provides an example of the mixed success of this strategy. See W. Morgan,
'Protecting Rights or Just Passing the Buck? The Human Rights (Sexual Conduct) Bill 1994', (1994) 1 Australian Journal of Human Rights 1. 
committees. ${ }^{139}$ The present antipathy of the Australian Government to these bodies is deeply regrettable, ${ }^{140}$ especially since they play such a key role in attending to some of the remedial deficiencies of the present system of implementation. Needless to say, in the absence of the availability of effective domestic remedies, it is unlikely that Australia's indirect forms of implementation comply with its international obligations.

This conclusion is consistent with the view of the CESCR, which has, like every other human rights treaty committee, ${ }^{141}$ regularly raised questions about Australia's lack of direct implementation of human rights. In 2000 the CESCR asked the Government to discuss the extent to which the ICESCR was incorporated into domestic law and to explain why it was excluded from the HREOC system. ${ }^{142}$ It also asked the Government to cite specific examples of its claim that human rights can in many cases be 'more readily promoted by less formal processes often associated with inquiry, conciliation and report'. ${ }^{143}$ Clearly dissatisfied with the responses it received, the CESCR concluded that the lack of legal status of the Covenant was 'impeding the full recognition and applicability of its provisions', ${ }^{144}$ and 'strongly' recommended that it be incorporated legislatively in order to ensure its applicability in domestic courts. ${ }^{145}$

Despite the CESCR's clear preference for direct incorporation of human rights into Australian law, there are many ways in which the Government could make its indirect measures of implementation more effective. If it did so, it would be in a better position to respond to questions about how the processes of inquiry, conciliation, and report are being used to meet the Government's obligations under the ICESCR, and to justify its use of indirect measures in terms of

139 Discrimination in the enjoyment of ICESCR rights will violate Art 26 of the ICCPR, which guarantees equal protection of the law. Further, racial discrimination in the enjoyment of economic, social, and cultural rights violates Art 5(e) of the International Convention on the Elimination of All Forms of Racial Discrimination 1965. Both of these instruments have individual complaints mechanms that have been ratified by Australia.

${ }^{140}$ See, further, D. Otto, "From "Reluctance" to "Exceptionalism": The Australian Approach to 141 See Concluding Oo of Human Rights', (2001) 26/5 Alternative Law Journal 219.

${ }^{141}$ See Concluding Observations of the Committee on the Elimination of Discrimination Against Women: Australia. 22/07/97, A/52/38/Rev.1, Part II, para 398; Concluding Observations of the Committee on the Rights of the Child: Australia. 10/10/97. CRC/C/15/Add.79, 10 Oct. 1997, para 24; Concluding Observations by the Committee on the Elimination of Racial Discrimination: Australia. 19/04/2000. CERD/C/304/Add.101, 19 Apr. 2000, para 6; Concluding Observations of the Human Rights Committee: Australia. 28/07/2000. A/55/40, paras 498-528, 28 July 2000; and Conclusions and Recommendations of the Committee Against Torture: Australia. 21/11/2000. CAT/C/XXV/Concl.3, 21 Nov. 2000, paras 7(a) and (b).

142 List of Issues, n. 121 above, para 7.

143 Ibid., para 9, referring to Third Periodic Report: Australia, n. 9 above, para 21.

144 Concluding Observations: Australia, n. 119 above, para. 13.

145 Ibid, para 24. The CESCR also encouraged the Government to follow the view of the High Court in Minister for Immigration and Ethnic Affairs $v$ Teob (1995) 183 CL R 237 that the ratifiction of an international human rights treaty gives rise to a legitimate expectation that administrative discretions will be exercised consistently with its terms. their appropriateness. With respect to SAAP, this would require establishing independent external mechanisms able to review the implementation of SAAP standards, as envisaged by the legislation. The Community Services (Complaints, Appeals and Monitoring) Act 1993 (NSW) established a watershed legislative framework, which could be emulated by other states. ${ }^{146}$ One of the bodies created was the Community Services Commission (CSC), which takes a multidimensional approach to ensuring that community services safeguard the rights and interests of consumers, including dealing with individual complaints. ${ }^{147}$ Yet even this progressive approach was, until recently, compromised by the CSC's inability to make decisions or recommendations that are inconsistent with government policy or resource allocation. ${ }^{148}$ As the 1999 review of the CSC by the New South Wales Law Reform Commission pointed out, this prevented the CSC from observing its primary guiding principle, which is to act in the best interests of the service user concerned. ${ }^{149}$ This restriction is an inappropriate means of providing for what the Second Reading Speech described as 'the primacy of the elected representatives of the people for policy determination and resource allocation', 150 because it prevents any criticism of government policies, which surely contradicts the democratic rationale of indirect forms of implementation. This situation was remedied in December 2002 by amendments which made the CSC a statutory division of the New South Wales Ombud's Office. This change had the effect of removing the restriction on criticizing government policies or resource allocation and has, in some other regards as well, strengthened the powers of the CSC. ${ }^{151}$ This example highlights the inherent conflict of interest in the government establishing 'independent' mechanisms that are able to review its decisions and those of Governmentfunded service providers. It suggests, as the CESCR has urged, that access to judicial remedies (direct implementation) may at some point be necessary to ensure the effectiveness of indirect forms of implementation and the result of progressive realization ${ }^{152}$ because, ultimately, the courts provide the best guarantee of independent monitoring and of effective remedies.

146 The legislation established four bodies: the Community Services Commission (CSC), the Community Visitors Scheme, the Community Services Review Council, and the Community Services Appeals Tribunal, which was reconstituted as the Community Services Division of the Administrative Decisions Tribunal in 1999.

${ }_{147}$ The CSC may also conduct reviews and inquiries, monitor standards, make recommendations about systemic issues, support the development of advocacy services for consumers, and play an educational role in relation to service providers and consumers.

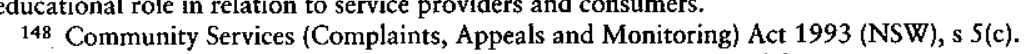

149 NSW Law Reform Commission, Report 90 (1999)-Review of the Community Services (Complaints, Appeals and Monitoring) Act 1993 (NSW), para 2.35.

150 New South Wales, Parliamentary Debates (Hansard), Legislative Assembly, 11 Mar. 1993, the
plaints, Appeals and Monitoring) Act 1993 (NSW), para 2.35. ${ }^{150}$ New South Wales, Parliamentary Debates (Hansard), Legislative Assembly,
Hon. J. Longley, Minister for Community Services, Second Reading Speech, 768.

Hon. J. Longley, Minister for Community Services, Second Reading Speech, 768.
151 Community Services Legislation Amendment Act 2002 (NSW). At the same time amendments were also made to the Ombudsman Act 1974 (NSW).

were also made to the Ombudsman Act 1974 (NSW). 


\section{CONCLUSIONS}

The Australian Government is in a unique position to develop, promote, improve upon, and extend the use of indirect measures of human rights implementation, given its singular resistance to legislative or constitutional entrenchment. Therefore, it might be expected that the Government's record in enhancing democratic participation in the implementation of rights, by promoting informed community debate about human rights in general and the distribution of social and economic goods in particular, would be exemplary. It might also be expected that substantial monitoring roles would be undertaken by a range of watchdog mechanisms, like human rights commissions, ombuds offices, policy coordination networks, and the like, which are particularly important for the protection of economic and social rights ${ }^{153}$ and also create opportunities for grass-roots engagement in 'dialogue' about rights. ${ }^{154}$ Yet, paradoxically, government funding of HREOC has been drastically reduced since 1996, and many of the national machineries that enhanced the ability of disadvantaged groups to participate in national policy development have been dismantled, most notably those that engaged indigenous people ${ }^{155}$ and women. ${ }^{156}$ Further, it is hard to understand why the ICESCR has not been scheduled to the HREOC Act 1986 (Cth), ${ }^{157}$ and why there is a dearth of benchmarks against which the Government's performance in delivering social and economic goods can be measured. ${ }^{158}$ It is difficult to take the Government's stated commitment to human rights seriously when there are such fundamental problems with its preferred approach to implementation, many of which have relatively easy solutions that are entirely consistent with democratic responsible government. In addition, the absence of appropriate remedial and accountability mechanisms places an unjustifiable burden on already overstretched international monitoring mechanisms.

153 B. von Tigerstrom, 'Implementing Economic, Social and Cultural Rights: The Role of National Human Rights Institutions', in I. Merali and V. Oosterveld (eds.), Giving Meaning to Economic, Social and Cultural Rights (Philadelphia: University of Pennsylvania Press, 2001), 139; M. Gomez 'Social Economic Rights and Human Rights Commissions', (1995) 17 Human Rights Quarterly 155 , 163.

J. Nedelsky and C. Scott, 'Constitutional Dialogue', in J. Bakan and D. Schneiderman (eds.) Social Justice and the Constitution: Perspectives on a Social Union for Canada (Ottawa: Carleton University Press, 1992), 59.

15s See Concluding Observations by the Committee on the Elimination of Racial Discrimination Australia 24/02/2000, CERD/C/56/Misc.42/rev.3, para 11.

156 See, for example, M. Sawer, 'The Watchers Within: Women and the Australian State', in L. Hancock (ed.), Women, Public Policy and the State (South Yarra: Macmillan Education Australia 1999), 36

157 'The Role of National Human Rights Institutions in the Protection of Economic, Social and Cultural Rights', CESCR General Comment No. 10, para 3: 'It is essential that full attention be give to economic, social and cultural rights in all of the relevant activities of these institutions.' Compil ation of General Comments, n. 23 above.

158 For example, in response to Australia's last periodic report the CESCR recommended that an official poverty line be established 'so that a credible assessment can be made of the extent of poverty in Australia'; Concluding Observations: Australia, n. 119 above, para 33.
However, even with the best systems of indirect implementation in place, it is likely that some questions will still remain about the appropriateness of Australia's primary reliance on indirect methods, especially in relation to independent review and the adequacy of remedies provided by political and administrative mechanisms. ${ }^{159}$ Consequently, there may still be a need for some form of direct implementation, especially in protecting the human rights of the most vulnerable groups in Australian society. ${ }^{160}$ While it is important to distinguish properly between the functions of courts and parliaments, and to respect parliamentary supremacy in a system of representative and responsible government, legal processes can nevertheless play an important role in implementing human rights. Legal forms of implementation need not insulate the interpretation and application of human rights from the political sphere, as the examples of Canada, New Zealand, and the United Kingdom show. The Australian optimism about the ability of democratic processes to protect human rights could lead to the development of a uniquely Australian system of 'dialogue' between the judicial and political arms of government, whereby the courts contribute to the public debate by giving human rights values more prominence than they would otherwise enjoy, as suggested by the Canadian experience. ${ }^{161}$ But first the dichotomizing of direct and indirect forms of implementation, between political and legal means of protecting rights, needs to be rejected. Once this is rejected, the question becomes one of the appropriate balancing of involvement of the two arms of government. A system that provides judicial review while still protecting parliamentary supremacy would, in my view, optimize the realization of outcomes that are consistent with Australia's international human rights obligations.

The monitoring of Australia's compliance with its international legal obligations under the ICESCR is of critical importance, as there is the real possibility that government policies of economic liberalization and the privatization of social services have resulted in a diminution of economic and social rights protections. While political processes are crucial to achieving effective and informed public participation in social policy formulation and economic decision-making that is consistent with Australia's international human rights obligations, legal processes can provide an essential check on the reasonableness or justifiability of governmental action in light of its effects on human well-being,

159 See, for example, the limited remedies available to conciliated disputes under federal antidiscrimination legislation; P. Bailey and A. Devereux, 'The Operation of Anti-Discrimination Laws in Australia', in D. Kinley (ed.), Human Rights in Australian Law (Sydney: Federation Press, 1998), 292, 305 .

160 B. Burdekin, 'The Impact of a Bill of Rights on Those Who Need it Most', in P. Alston (ed.) Towards an Australian Bill of Rights (Canberra: Centre for International and Public Law and HREOC, 1994), 147, 153.

${ }_{161}$ P. W. Hogg and A. A. Bushell, 'The Charter Dialogue Between Courts and Legislatures (Or Perhaps the Charter of Rights Isn't Such a Bad Thing After All)', (1997) 35 Osgoode Hall Law Journal 75 . 
and ensure that fundamental guarantees of human dignity are safeguarded. Until both systems are working more effectively, and in dialogue with each other, it is wrong for the Australian Government to claim, as it does, an exemplary record in fulfilling its international human rights obligations. 


\section{University Library}

\section{- M M I N E R VA A gateway to Melbourne's research publications}

Minerva Access is the Institutional Repository of The University of Melbourne

Author/s:

OTTO, DL

Title:

Addressing homelessness: does Australia's indirect implementation of human rights comply with its international obligations?

Date:

2003

Citation:

OTTO, D. L. (2003). Addressing homelessness: does Australia's indirect implementation of human rights comply with its international obligations?. CAMPBELL, T (Ed.).

GOLDSWORTHY, J (Ed.). STONE, A (Ed.). Protecting human rights: instruments and institutions, (1), pp.281-306. Oxford University Press.

Persistent Link:

http://hdl.handle.net/11343/25400 